\title{
Chemical and Biological Contamination of Drinking Water as Affected by Residual Chlorine Deterioration and Storing Period: Case Study in Sinai, Egypt
}

\author{
Hussein I. Abdel-Shafy ${ }^{1^{*}}$, Mona S.M. Mansour ${ }^{2}$ and Sally H. Abdel-Shafy ${ }^{\mathbf{3}}$ \\ ${ }^{1}$ Water Pollution Research and Control Department, National Research Centre, Dokki, \\ Cairo, Egypt, ${ }^{2}$ Analyses \& Evaluation Department, Egyptian Petroleum Research \\ Institute, 1 Ahmed El-Zomor Street, Nasr City, Cairo. Egypt, ${ }^{3}$ National Research \\ Centre, Dokki, Cairo, Egypt.
}

\begin{abstract}
$\mathbf{T}$ HE PRESENT investigation focuses on the chemical and biological contamination of drinking water as a case study in El-Taquaddum area in Sinai, Egypt. This area used to suffer from deficiency of clean drinking water. The present study investigated the effect of residual chlorine deterioration and the storing period on the chemical and biological quality of drinking water. The results obtained revealed that storing drinking water for long time in closed or open storing tanks deteriorate the residual chlorine that affected the chemical characteristics and biological contamination of drinking water. Correlation between the closed storing tanks and the open ones in terms of the chemical and biological quality of drinking water as affected by the residual chlorine was studied extensively.
\end{abstract}

This investigation reveals that the residual chlorine in drinking water is the controlling factor in preventing the presence of coliform bacteria and other biological contaminants. The continuous supply of freshly chlorinated water is important to keep the level of residual chlorine on the safe border. However, increasing the storage time of drinking water affects dramatically on the available residual chlorine, and thus effects the presence of several contaminants including insects, coliform bacteria, and fungi. Therefore, it was strongly recommended to avoid storing the drinking water in open tanks in order to prevent any chemical and/or biological contamination. Nevertheless, filtration through regular home filter that consists of ceramic filter and UV device could eliminate the presence of contaminants including suspended chemicals, bacteria, insects, fungi and turbidity. It also improved the chemical characterization of drinking water.

Keywords: Drinking water, Chemical contamination, Residual chlorine in drinking water, Biological contamination, Drinking water in Sinai, Storing drinking water, Filtration of drinking water.

\section{Introduction}

Sinai area is a peninsula in Egypt that characterized by deficiency of water resources [1-4]. Meanwhile, Drinking Water Treatment Plants (DWTP) in Sinai is facing with limited water supplies. Sources of fresh water to Sinai are supplied mainly from the Nile Valley [4]. As an example the DWTP in El-Taquaddum area supplies water to the village for successive 5 days followed by another 5 days without any water supply [4]. During these days the water is directed to agriculture purposes. Thus, the inhabitants of El-Taquaddum area have to store their water in PVC storing tanks on the roof of their homes. Due to the long storing time, the quality of such water should be examined carefully in terms of any chemical and biological contamination [4].

*Corresponding author e-mail: hshafywater@yahoo.com, waterbiotech@yahoo.com.

Tel. +2-01224018017

DOI: $10.21608 /$ ejchem.2017.1488.1106

(C)2017 National Information and Documentation Centre (NIDOC) 
It was recorded that an epidemic of Cholera and Typhoid were dramatically spread in London due to the contamination of water by sewage [5]. It is well known that chemical contamination of drinking water represents a fatal health risk to Man and organic lives as well. Meanwhile, it is well documented that coliform test is used as an indicator of sewage contamination originated from intestinal organisms [6]. Therefore, the chemical and bacteriological examination of fecal coliform is essential for a safe drinking water as well as the swimming water. Nevertheless, proper and accurate interpretation of results should be achieved within the field monitoring to reveal if there are possible sources of chemical or biological contamination $[4,7]$.

In most Drinking Water Treatment Plant (DWTP), the conventional disinfection method is achieved by the addition of chlorine to the treated water to assure biological safety[4]. It is well known that chlorine has bactericidal disinfection effect [4]. However, chlorine also reacts rapidly with certain organic compounds to form variable chloramines compounds. Within thirty minutes of contact time with water and at neutral $\mathrm{pH}$, the residual free chlorine can be detected. This is the uncombined chlorine that kills the bacteria $[8,9]$. If the chloramines are formed, thus; extra chlorine is required within the range of 2 to $3 \mathrm{mg} / \mathrm{l}$ to compensate for the consumed chlorine depending on the waters $\mathrm{pH}$ [10].To get rid of viruses, it requires between 3 to $4 \mathrm{mg} / \mathrm{l}$ of chlorine at a $\mathrm{pH}$ 8[7]. On the other hand, Fungi are ubiquitous chlorophyllous heterotrophic organisms that are characterized by an organized nucleus[7]. Fungi are a large and diverse group of encaryotic organisms. In the aquatic environment, this group is active in degrading organic substrates [11]. Fungi can be found wherever non-living organic matters occurs [11]. Some species are pathogenic and others are parasitic[11]. Near the source of spring water, the number of fungus spores is usually minimal $[9,11]$. Heavily contaminated waters possess large numbers of soil fungi [11].Thus, the association of fungus and organic load as contaminants suggests that fungi is a useful as powerful indicators of pollution in the environment [12]. However, no specific or single species or group of fungi can be identified as important in such indication of pollution [9]. The amount of residual chlorine or other chemical disinfectants that are required for fungus control is variable[4]. In this respect, some fungi, particularly the Trychomycetes have their own amoeboid stages [7]. Such fungi inhabit the hind gut of certain worms, mosquito larvae, etc... $[12,13]$. Storing drinking water in open tanks to the atmosphere could be the main source of chemical and biological contamination including fungal input, source of worms, mosquito larvae and flies $[12,13]$.

The objective of the present study is to investigate the impact of storing drinking water for long time in open storing tanks in this case study in Sinai. The study includes the investigation of any possible chemical or biological contamination including turbidity, suspended solids as well as the presence of bacteria, fungi and insects as a result of such storing practice. Additional aim of the present investigation is to evaluate the chemical and biological characteristics of drinking water in the open storing tanks for variable periods of days. Correlation between the closed storing tanks and the open ones in terms of the quality of water is another aim of this work. The study includes the effect of water filtration for the removal of any possible chemical or biological contamination.

\section{Materials and Methods}

An intensive sampling program was designed to collect drinking water samples from different open and close storing tanks that were used to keep drinking water in a selected area, namely, El-Taquaddum in Sinai. The samples were taken every two successive weeks for a period of 6 months continuously. This drinking water was previously treated by the local Drinking Water

All drinking water samples were collected from the storage tanks of different seven houses of the village. The selected seven houses are given serial numbers from 1 to 7 . The collected water samples were subjected to the following examinations:

1. Physical and chemical characteristics,

2. Residual chlorine,

3. Microbiological examinations,

4. Microscopic examination,

5. Detection of fungi

\section{Physical and chemical examination}

The physical and chemical characteristics of drinking water including turbidity and residual chlorine were immediately determined in situ in freshly collected samples according to "Standard Methods"[14]. The physical characteristics included $\mathrm{pH}$, Temperature, and electric conductivity were also determined. The chemical 
characteristics include: total dissolved solids, chlorides, residual chlorine, sodium, potassium, calcium, nitrates, nitrites, and phosphate were also investigated. For the detection of residual chlorine, the stored water samples were daily collected for a period of five days. The daily drinking water samples were also collected for a period of two weeks for the detection of the presence of any insects. The samples were collected in sterile bottles to avoid any biological contamination.

\section{Microscopic examination}

Detection of insect contamination

One liter sample of the stored water is collected for detection of any type of insects. The stereomicroscope is used to classify the insects.

\section{Fungi examination}

Primary examination was carried out to investigate the presence of fungi using the microscopic examination of the freshly collected and stored water samples. Thus, one $\mathrm{ml}$ of each sample was introduced into a Petri-dish and was examined under a stereomicroscope at a magnification of (x 40). The concentrations and prevalence of different fungi structures were estimated. The grown fungi on sabouraud media and incubated at $22^{\circ} \mathrm{c}$ were also investigated and classified. Fungal colonies were isolated by transferring to slants of sabouraud dextrose agar according to APHA [14]. Each one $\mathrm{ml}$ of these isolated colonies was examined for the detection of the Fungi.

Microbiological examinations: Detection of bacterial contamination
The coliform bacteria were determined in the drinking water samples according to the Standard Methods[14]. This study was carried out by examining five different replicates from each water samples.

Filtration of the stored water:

The stored water was allowed to flow through a regular home filter that is consists of five successive units. The filtration system includes one carbon column and one ceramic column. Water samples of the inlet and the outlet of the filter were examined for the detection of fungi, bacterial count and physical/chemical characterization.

\section{Results and Discussions}

Physical and chemical characteristics of the drinking water

The physical and chemical characteristics of the collected DW from both closed and open storing tanks that were stored for 5 days were determined (Table 1). The samples were collected from 7 different locations. The given results showed that the open storing tanks are; generally; characterized by higher turbidity and TDS in correlation with the closed tanks (Table 1).

It can be noticed that within 5 days the residual chlorine was completely disappeared in all the studied open and closed storing tanks. After 4 days in closed storing tanks, only 3 out of the 7 samples contained $0.1 \mathrm{mg} / 1$ residual chlorine (Table 2). Such residual chlorine disappeared in the rest of the samples (i.e. zero $\mathrm{mg} / \mathrm{l}$ residual chlorine).

TABLE. 1. Physical and chemical characteristics of drinking water samples that were stored for 5 days in El-Taqaddum area, Sinai. Water was stored in either closed or open tanks.

\begin{tabular}{|c|c|c|c|c|c|c|c|c|c|c|c|c|c|c|}
\hline \multirow[t]{2}{*}{ Parameters } & \multicolumn{2}{|c|}{ sample 1} & \multicolumn{2}{|c|}{ sample 2} & \multicolumn{2}{|c|}{ sample 3} & \multicolumn{2}{|c|}{ sample 4} & \multicolumn{2}{|c|}{ sample 5} & \multicolumn{2}{|c|}{ sample 6} & \multicolumn{2}{|c|}{ sample 7} \\
\hline & Closed & open & closed & open & closed & open & closed & open & closed & open & closed & open & closed & open \\
\hline pH & 7.2 & 7.1 & 7.5 & 6.9 & 7.1 & 7.4 & 7.2 & 7.0 & 7.1 & 6.8 & 7.5 & 8.2 & 7.8 & 7.1 \\
\hline TEMP. $C^{\circ}$ & 24 & 17 & 26.5 & 34 & 26.5 & 35 & 25.5 & 34 & 26.5 & 34 & 27.5 & 34 & 25 & 33 \\
\hline Turb. (NTU) & 0.30 & 7.42 & 0.58 & 6.78 & 0.35 & 5.48 & 0.51 & 6.78 & 0.35 & 6.51 & 0.30 & 7.57 & 0.32 & 6.59 \\
\hline $\mathrm{EC}(\mu \mathrm{S})$ & 370 & 380 & 354 & 398 & 372 & 399 & 352 & 399 & 280 & 389 & 338 & 399 & 332 & 388 \\
\hline T.D.S. (mg/l) & 179 & 230 & 208 & 238 & 191 & 212 & 205 & 238 & 188 & 217 & 207 & 245 & 190 & 207 \\
\hline Chlorides (mg/l) & 45 & 46 & 49 & 49 & 43 & 42 & 45 & 45 & 44 & 45 & 41 & 41 & 45 & 45 \\
\hline $\mathrm{Na}(\mathrm{mg} / \mathrm{l})$ & 10.5 & 12.9 & 11.9 & 13.1 & 10.8 & 11.9 & 12.5 & 13.7 & 12.0 & 16.2 & 13.1 & 16.8 & 10.6 & 13.9 \\
\hline K (mg/l) & 1.3 & 1.6 & 1.2 & 1.5 & 1.3 & 1.7 & 1.4 & 1.5 & 1.2 & 1.6 & 1.1 & 1.5 & 1.3 & 1.7 \\
\hline $\mathrm{Ca}(\mathrm{mg} / \mathrm{l})$ & 0.5 & 0.6 & 0.6 & 0.7 & 0.5 & 0.6 & 0.6 & 0.7 & 0.7 & 0.9 & 0.5 & 0.7 & 0.6 & 0.8 \\
\hline Nitrate (mg/l) & Nil & Nil & Nil & Nil & Nil & Nil & Nil & Nil & Nil & Nil & Nil & Nil & Nil & Nil \\
\hline Nitrite (mg/l) & Nil & Nil & Nil & Nil & Nil & Nil & Nil & Nil & Nil & Nil & Nil & Nil & Nil & Nil \\
\hline Phosphate, (mg/l) & Nil & Nil & Nil & Nil & Nil & Nil & Nil & Nil & Nil & Nil & Nil & Nil & Nil & Nil \\
\hline
\end{tabular}


The level of other chemical parameters including chlorides, sodium, potassium, calcium, nitrates, nitrites, and phosphate was slightly increased in the open tanks compared to the closed tanks.

Effect of the storing time of the residual chlorine:

Results in Table 2 shows that the initial concentration of the residual chlorine was 2.7 $\mathrm{mg} / \mathrm{l}$. A noticeable decrease in this concentration was determined in both closed and open tanks. Thus, a remarkable decrease in the residual chlorine in stored water was recorded as the storing time increase (Table 2). This decrease was true in both closed and open storing tanks. In the closed tank, residual chlorine decreased within one day by the rate of $44.4 \%$ (i.e. the residual chlorine decreased from 2.7 to $1.5 \mathrm{mg} / \mathrm{l})$. In the open tank, the residual chlorine decreased by the rate of $59 \%$ during the same time (i.e. from 2.7 to $1.1 \mathrm{mg} / \mathrm{l})$. Furthermore, in the closed tank, residual chlorine disappeared after four days. But it took only two days for the residual chlorine to disappear in the open tank.

Role of storing time of drinking water on the contamination with insects:

The fresh water was subjected to the microscopic examination for the detection of any type of insects or insect's stages (larva, pupa and adult) in the studied samples (Table 3 ). The open tank exhibited the presence of several insects during the storing periods. After storing the water for four days, two individuals of two different insect species were found namely Cataglyphis bicolor F. Formicidae O. Hymenoptera and Culex pipiens (larva) F. Culicine O. Diptera and they were found dead. Increasing the storing time showed a gradual increase in the insect's density to 11,24 and 36 after 7, 10 and 12 days, respectively (Table 3). Within 14 days the open tank received 51 different insects (Table 3). Several insects were detected during the period of investigation. On the contrary, the closed tank was completely protected (Table 3), where no presence of any insect was detected. This can be attributed to the continuous replacement of fresh water in the tanks for the daily consumption. Thus, the residual chlorine in the fresh water is another factor to support the quality of water in the closed tank. Therefore, it is important to stress on storing drinking water in clean and well closed tanks.

It is worth mentioning that some of the investigated insects were found in active stage like larva of Culex mosquito, others were found in adult Egypt. J. Chem. 60, No. 6 (2017) stage like dead ants, house fly, and some beetles (order Coleoptera). Examination of these insects indicated that the majority were non-aquatic and were found dead. There is no doubt that the source of these insects was the surrounding environment. All the detected insects fell down into the open stored tanks water. However, certain aquatic insects like mosquitoes are; usually; searching for an aquatic medium to lay their eggs on the water surface, which after hatching they give rise to mosquito larvae in active stage $[13,15]$.

\section{Micro-biological contamination of the stored} drinking water:

The role of insects in the contamination of drinking water by microorganisms was studied. This investigation was carried out for the detection of both fungal and bacterial contamination in the stored drinking water in comparison to the presence of the same contaminants as well as the presence of insect and/or the residual chlorine according to the storing time (Table 4). The given results showed that the contamination by bacteria took place in both the open and the closed storing tanks in relation to the disappearance of chlorine (Table 4). In the open tanks, the total bacterial coliform count reached 2.1 as MPN- index $/ 100 \mathrm{ml}$ after 6 days storing period. By increasing this storing period the bacterial coliform count increased to $8.9,12.8,15.0$ and $>15$ as MPN- index $/ 100 \mathrm{ml}$ after $8,10,12$ and 13 days respectively. During these periods the residual chlorine $(\mathrm{mg} / \mathrm{l})$ was down to zero $\mathrm{mg} / \mathrm{l}$ (i.e. disappeared completely) (Table 4). On the other hand, the bacterial coliform count was also detected in the closed tank after the disappearance of the residual chlorine (Table 4). The results showed that after 7 days the bacterial coliform count was 1.0 as MPN- index /100. By storing the drinking for longer time, the bacterial count increased by increasing the storing time. By storing this water up to 14 days, the bacterial coliform count reached 9.1 as MPN- index /100 (Table 4).

It is important to mention that there is a close relation between the presence of insects and the bacterial coliform count in the open tanks (Table 4). Increasing the density of the accumulated insect increases the bacterial coliform count (Table 4).

Drinking water contamination with Fungi as affected by storing period:

Role of chlorine on the density of fungi was studied extensively. Contamination of the stored water with fungi was determined in the studied 
TABLE 2. Residual chlorine as affect by the storing time of drinking water in either closed or open tanks.

\begin{tabular}{ccc}
\hline \multirow{2}{*}{ Storing Time (days) } & \multicolumn{2}{c}{ Residual Chlorine (mg/l) } \\
\cline { 2 - 3 } & Open Tank & Closed Tank \\
\hline 1 & 2.7 & 2.7 \\
2 & 1.1 & 1.5 \\
3 & 0.0 & 0.2 \\
4 & 0.0 & 0.1 \\
5 & 0.0 & 0.0 \\
6 & 0.0 & 0.0 \\
7 & 0.0 & 0.0 \\
8 & 0.0 & 0.0 \\
9 & 0.0 & 0.0 \\
10 & 0.0 & 0.0 \\
11 & 0.0 & 0.0 \\
12 & 0.0 & 0.0 \\
13 & 0.0 & 0.0 \\
14 & 0.0 & 0.0 \\
\hline
\end{tabular}

TABLE 3. Role of storing time of drinking water on the presence of insects in opened and closed tanks.

\begin{tabular}{|c|c|c|c|c|c|c|c|c|c|c|c|c|c|c|c|c|}
\hline \multirow{2}{*}{$\begin{array}{l}\text { Classfication } \\
\text { Number of insects }\end{array}$} & \multicolumn{14}{|c|}{ Storing time (disy) and Number of insects } & \multirow{2}{*}{$\begin{array}{l}\text { Opened } \\
\text { Tank }\end{array}$} & \multirow[t]{2}{*}{ Closed tank } \\
\hline & 1 & 2 & $\overline{3}$ & 4 & 5 & 6 & 7 & 8 & 9 & 10 & 11 & 12 & 13 & 74 & & \\
\hline $\begin{array}{l}1 \text { Cataglyphis bicolor F. } \\
\text { Fosmicidae 0. Hymenoptera }\end{array}$ & 0 & fl & $\overline{0}$ & 1 & 1 & 1 & 1 & 1 & 1 & 1 & 1 & 1 & 2 & & 11 & a \\
\hline $\begin{array}{l}2 \text { Culex pipiens (larva) F. } \\
\text { culicine 0. Diptera }\end{array}$ & 0 & 7I & 0 & (10 & 0 & a & 1 & 1 & 1 & 1 & 1 & $\overline{1}$ & $\overline{1}$ & $\overline{1}$ & 8 & a \\
\hline $\begin{array}{l}3 \text { Monomorium sp F. } \\
\text { Fromicidas: Hymenoptera }\end{array}$ & 0 & f & 0 & 0 & 1 & 1 & 0 & 1 & 1 & 1 & 1 & 1 & 1 & 1 & 9 & 0 \\
\hline $\begin{array}{l}4 \text { Phyllotrda crucifora F. } \\
\text { Crysomelidae 0. Coleopters }\end{array}$ & 0 & fl & 0 & a & 0 & a & 1 & 1 & 1 & 0 & 1 & 1 & 0 & 0 & 5 & a \\
\hline $\begin{array}{l}5 \text { Musca domestica F. } \\
\text { Muscidac 0. D }\end{array}$ & 0 & (1) & 0 & a & 0 & a & 0 & 1 & 1 & 1 & 1 & 1 & 1 & 2 & 8 & 0 \\
\hline $\begin{array}{l}6 \text { Grylotalpa gryllatalpa } 0 . \\
\text { Orthopters }\end{array}$ & 0 & 11 & 0 & (1) & 0 & (1) & 0 & 1 & 1 & 1 & 1 & 2 & $\overline{1}$ & 1 & 8 & a \\
\hline $\begin{array}{l}7 \text { Periplanefa americarat } \mathrm{F} \text {, } \\
\text { Blattidae Q Dictyoptera }\end{array}$ & 0 & 0 & 0 & 0 & 0 & 0 & 0 & 0 & 0 & 0 & 0 & 0 & 1 & 1 & 2 & 0 \\
\hline $\begin{array}{l}\text { Total numbers of inserts in } \\
\text { the water Tank }\end{array}$ & 0 & 0 & 0 & 2 & 2 & 3 & 4 & 5 & 4 & 4 & 6 & 6 & $\bar{B}$ & 7 & 51 & $\bar{a}$ \\
\hline
\end{tabular}

Egypt. J. Chem. 60, No. 6 (2017) 
TABLE 4. Residual chlorine, and total coliform count and the accumulated number of insects as affect by the storing time of drinking water in either closed or open tanks.

\begin{tabular}{|c|c|c|c|c|c|c|c|}
\hline \multirow{2}{*}{$\begin{array}{l}\text { Storing Time } \\
\quad \text { (days) }\end{array}$} & \multirow{2}{*}{$\begin{array}{l}\text { Accumulated Number of } \\
\text { Insects in the open tank }\end{array}$} & \multicolumn{2}{|c|}{$\begin{array}{c}\begin{array}{c}\text { Residual Chlorine } \\
(\mathrm{mg} / \mathrm{l})\end{array} \\
\end{array}$} & \multicolumn{2}{|c|}{$\begin{array}{l}\text { Total Coliform count } \\
\text { (MPN-100/mL) }\end{array}$} & \multicolumn{2}{|c|}{ Fungal Count "Colony" } \\
\hline & & Open Tank & Closed Tank & Open Tank & Closed Tank & Open Tank & Closed Tank \\
\hline 1 & 0 & 2.7 & 2.7 & 0.0 & 0.0 & 0.0 & 0.0 \\
\hline 2 & 0 & 1.1 & 1.5 & 0.0 & 0.0 & 0.0 & 0.0 \\
\hline 3 & 0 & 0.0 & 0.2 & 0.0 & 0.0 & 0.0 & 0.0 \\
\hline 4 & 2 & 0.0 & 0.1 & 0.0 & 0.0 & 0.0 & 0.0 \\
\hline 5 & 4 & 0.0 & 0.0 & 0.0 & 0.0 & 0.0 & 0.0 \\
\hline 6 & 7 & 0.0 & 0.0 & 2.1 & 0.0 & 0.0 & 0.0 \\
\hline 7 & 11 & 0.0 & 0.0 & 5.0 & 1.0 & 0.0 & 0.0 \\
\hline 8 & 16 & 0.0 & 0.0 & 8.9 & 1.3 & 3 & 0.0 \\
\hline 9 & 20 & 0.0 & 0.0 & 10.9 & 2.9 & 4 & 1 \\
\hline 10 & 24 & 0.0 & 0.0 & 12.8 & 3.8 & 5 & 2 \\
\hline 11 & 30 & 0.0 & 0.0 & 13.9 & 4.9 & 5.5 & 3 \\
\hline 12 & 36 & 0.0 & 0.0 & 15.0 & 5.3 & 5.5 & 3.5 \\
\hline 13 & 44 & 0.0 & 0.0 & 16 & 7.5 & 6.5 & 4.0 \\
\hline 14 & 51 & 0.0 & 0.0 & 17 & 9.1 & 6.5 & 4.5 \\
\hline
\end{tabular}

water samples in both closed and open tanks. Level of chlorine in relation to the density of fungi was similarly investigated. The results obtained are shown in Table 4. These results indicate a variation in the density of Fungi in relation to the residual chlorine in the storing tanks. The contamination in the open storing tanks was higher with fungi colonies than the closed tanks (Fig. 1). Fungi colonies were first detected in the closed tank in the $9^{\text {th }}$ day. Before the $9^{\text {th }}$ day, stored water in the closed tanks was clear from any fungus contamination (Table 4). On the other hand, the fungi colonies in the open storing tank were detected on the $8^{\text {th }}$ day (Table 4). Meanwhile, the results showed that increasing the storing time in the closed tanks increases the fungi colonies, where the fungi colonies increased up to 2, 3, 4, and 5 after storing for 10, 11, 13, and 14 days respectively (Table 4). The results are also illustrated in Fig. 2. Furthermore, the results (Table 4) indicated that the fungi colonies in the open tanks were higher than that in the closed tanks, where the fungi colonies were $4,5,5.5$, and 6.5 corresponding to storing period of $9,10,11$ and 13 days. The presence of fungi may be attributed to the disappearing of chlorine in the stored water. Figure 3 illustrates the incrrase in the presence of both insects and the coliform count in the open tanks. This results indicates that increasing thr number of insects increases the coliform count.

The studied samples were further examined for the investigation of the different fungi species in the stored drinking water. The densities of certain species were found in remarkable variation. These species were Fusarium sp., Aspergillus Niger, Penicillium sp., Mucorales risobs, and Caldosporidium pegmentedis. However, the most abundant species was Aspergillus Niger. Meanwhile, the density of the other investigated species was found in fewer quantities with variable density from sample to another. Thus, the density of fungi can be arranged in most of the samples according to the following decreasing order:

Peniciliursp.>AspergillusNiger $>$ Mucoralesrisobs

It was noticed also that Aspergillus Niger and Penicillus sp. were disappeared in some collected samples. Meanwhile, Mucorales risobs were predominant in the same samples. On the contrary, in some other samples Mucorales risobs were disappeared while Aspergillus Niger was predominant. It is important to mention that some Caldosporidium pegmentedis sp. was found mainly in the samples collected from the sites 3, 5 and 7.

Thus, it can be confirmed from the given results that storing water in the closed tanks prevents the contamination by insects, fungi and bacteria.

Filtration of the stored water:

Water filtration is well known process for the removal of suspended solids as well as certain biological contaminants including algae, bacteria, and Fungi[16]. The efficiency of removal depends on several factors including the type, pore size and the media of the filter[16-17]. The flow rate 


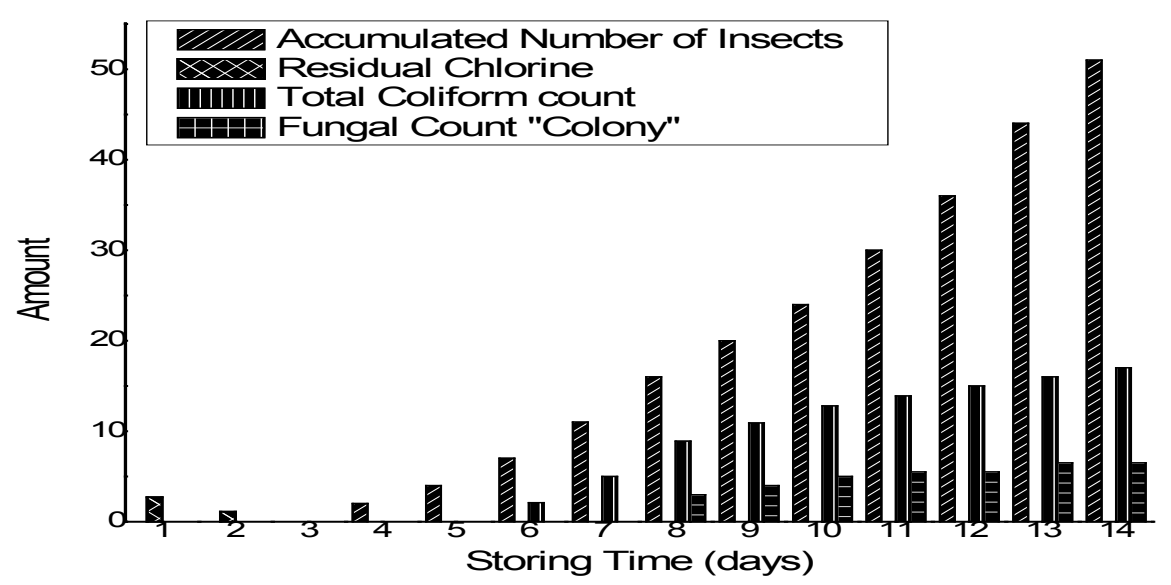

Fig. 1. Amount of accumulated number of insects, residual chlorine, total coliform count and fungal count "colony" in the opened tank during 14 days of drinking water storage.

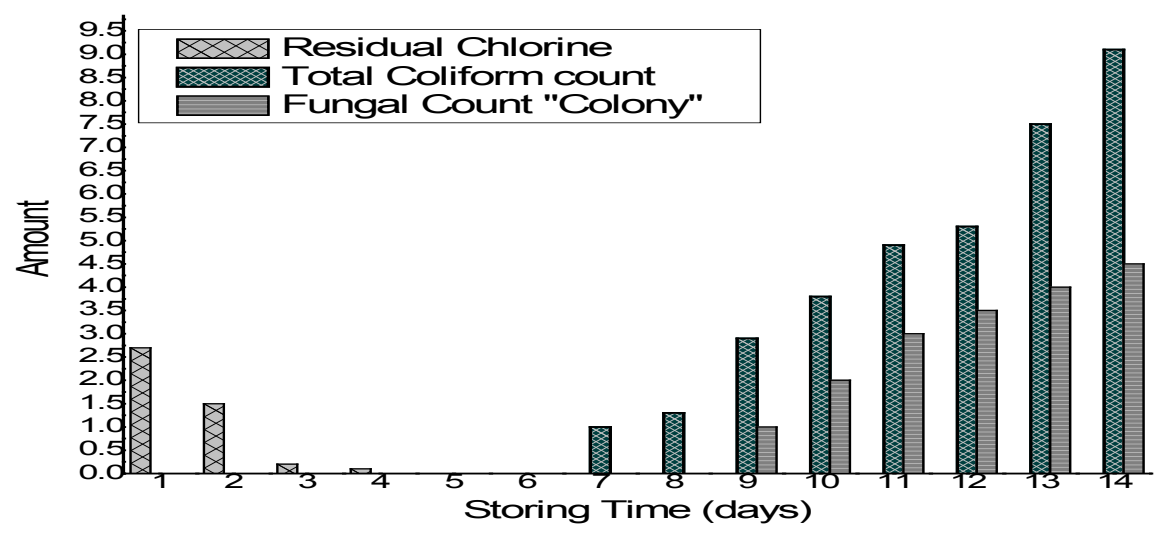

Fig. 2. Amount of residual chlorine, total coliform count and fungal count "colony" in the closed tank during 14 days of drinking water storage.

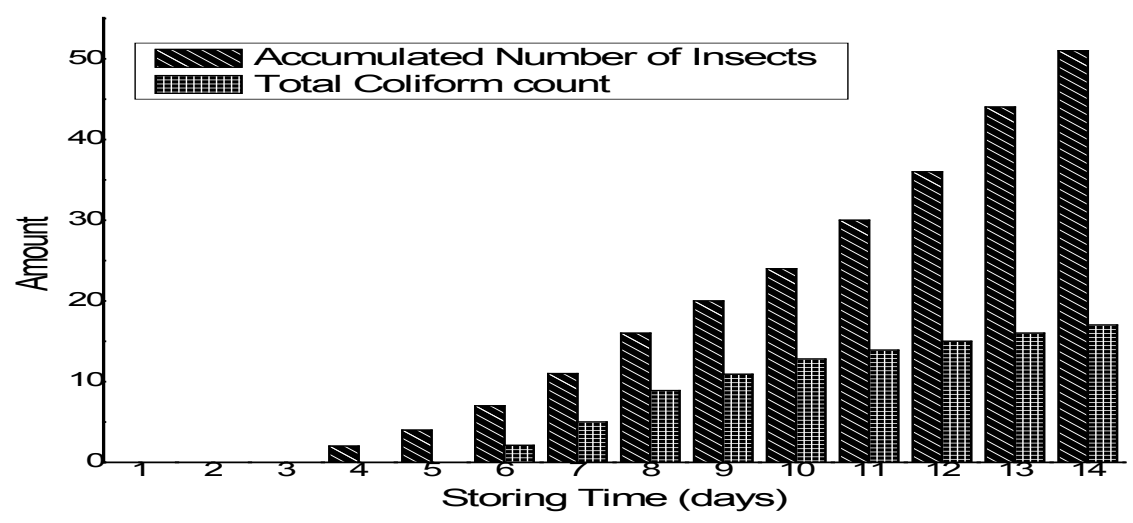

Fig. 3. Amount of accumulated number of insects and total coliform count in the opened tank during 14 days of drinking water storage. 
is another controlling factor[16]. Filters that are regularly used at home are very common these days. That is why it was found important to examine the efficiency of such filters on the removal of fungi, bacteria, turbidity and other contaminants from the stored water.

Results obtained (Table 5) showed that the 5 units filter is capable of removing the studied biological contaminants including turbidity, bacteria, and Fungi. The dead insects were, probably, retained out of the filter pores. The bacterial count and the fungi count were both below minimum detection limits (Table 5). This could be attributed to the presence of UV device as a column that is responsible for the disinfection of bacteria. Meanwhile, the removal or the retaining of fungi is referred to the presence of ceramic filter as micro-filter among the filtration system that retained the fungi.

These results indicate that the home filter system is capable of removing the contamination of the stored drinking water; namely; the bacteria and fungi. It could also retain the insects and decreases the turbidity as well.

\section{Conclusions and Recommendations}

Storing drinking water in open tanks is absolutely hazard due to loss of chlorine that prevents the water from bacterial contamination. Meanwhile, the open tank is greatly exposed to the falling insects, fungi, etc... Falling insects in water can be the source for other contaminants such as bacteria, fungi, and turbidity.

Thus, storing drinking water in well closed tanks is important. Nevertheless, storing water for more than 2 days is not recommended to prevent the possibility of contamination as a result of chlorine disappearance.

On the other hand, storing drinking water in the closed tanks is important but the storing time should not exceed 2 days. Meanwhile, the residual chlorine in drinking water is the controlling factor to prevent the presence of coliform bacteria. This can be attributed to the continuous supply of freshly chlorinated water.

From these results it can be concluded that increasing the storage time of the water affects dramatically on the available residual chlorine, and thus effects the presence of other contaminants including coliform bacteria, and fungi.

TABLE 5. Filtration of stored Drinking water through domestic home filter (water was previously stored for 10 days).

\begin{tabular}{|c|c|c|c|c|c|}
\hline \multirow[b]{2}{*}{ Parameter } & \multirow[b]{2}{*}{ Unit } & \multicolumn{2}{|c|}{ Stored drinking water } & \multicolumn{2}{|c|}{ Filtered Drinking water } \\
\hline & & $\begin{array}{l}\text { Closed } \\
\text { tank }\end{array}$ & $\begin{array}{l}\text { Opened } \\
\text { tank }\end{array}$ & Closed tank & $\begin{array}{c}\text { Opened } \\
\text { tank }\end{array}$ \\
\hline $\mathbf{P H}$ & $\cdots \cdots$ & 7.4 & 7.5 & 7.3 & 7.4 \\
\hline $\begin{array}{l}\text { Total suspended solids } \\
\text { (TDS) }\end{array}$ & $\mathrm{mg} / \mathrm{l}$ & 216 & 230 & 215 & 230 \\
\hline $\begin{array}{l}\text { Electric conductivity } \\
\text { (E.C.) }\end{array}$ & $\mathrm{ms}$ & 350 & 385 & 344 & 380 \\
\hline Chloride (Cl) & $\mathrm{mg} / \mathrm{l}$ & 45.8 & 49.7 & 43.6 & 45.5 \\
\hline Nitrite $\left(\mathrm{NO}_{2}\right)$ & $\mathrm{mg} / \mathrm{l}$ & 0.02 & 0.01 & BDL & BDL \\
\hline Nitrate $\left(\mathrm{NO}_{3}\right)$ & $\mathrm{mg} / \mathrm{l}$ & BDL & BDL & BDL & BDL \\
\hline Phosphate $\left(\mathrm{PO}_{4}\right)$ & $\mathrm{mg} / \mathrm{l}$ & BDL & BDL & BDL & BDL \\
\hline Turbidity & NTU & 0.32 & 22.7 & 0.56 & 6.9 \\
\hline Residual chlorine & $\mathrm{mg} / \mathrm{l}$ & 0.0 & 0.0 & 0.0 & 0.0 \\
\hline Sodium (Na) & $\mathrm{mg} / \mathrm{l}$ & 10.3 & 18 & 10.1 & 16.9 \\
\hline Calcium (Ca) & $\mathrm{mg} / \mathrm{l}$ & 0.5 & 0.6 & 0.5 & 0.6 \\
\hline Potassium (K) & $\mathrm{mg} / \mathrm{l}$ & 1.3 & 1.5 & 1.3 & 1.5 \\
\hline Fungi & & 2 & 5 & BDL & BDL \\
\hline Total Coliform count & $\begin{array}{l}(\mathrm{MPN}- \\
100 / \mathrm{mL})\end{array}$ & 3.8 & 12.8 & BDL & BDL \\
\hline $\begin{array}{l}\text { Insects } \quad \text { (Total } \\
\text { accumulated numbers) }\end{array}$ & & o & 24 & BDL & BDL \\
\hline
\end{tabular}

DWTP $=$ drinking water produced by the local treatment plant (stored for 10 days)

$\mathrm{BDL}=$ below detection limits

Egypt. J. Chem. 60, No. 6 (2017) 
Therefore, it is strongly recommended to avoid storing the drinking water in open tanks in order to prevent any biological contamination. Furthermore, it can be concluded from the obtained results that filtration through regular home filter that consists of ceramic filter and UV device could eliminate the presence of contaminants including bacteria, insects, fungi and turbidity.

\section{Acknowledgment}

The authors wish to express their deep appreciation and gratitude to the facilities provided by the project titled "Sustainable Development for Wastewater Treatment and Reuse via Constructed Wetlands in Sinai (SWWTR)" that is funded by STDF of Egypt.

\section{References}

1. Abdel-Shafy H.I., and Aly R.O., Water issue in Egypt: resources, pollution and protection endeavors Central European J. of Occupational \& Environ. Medicine, Vol. 8 (1): 1-21 (2002).

2. Abdel-Shafy Hussein I. and Mansour Mona S.M., Overview on water reuse in Egypt: Present and Future, J. Sustainable Sanitation Practice, Vol. 14, pp. 17-25 (2013).

3. Abdel-Shafy Hussein I. and Aly R.O., "Wastewater Management in Egypt” In "Wastewater Reuse-Risk Assessment, Decision-Making and Environmental Security" Mohammed K. Zaidi (Ed) Springer Publisher, Netherland, pp.375-382 (2007).

4. Abdel-Shafy Hussein I., Salem Mohamed A., Mansour Mona S. M. , El-Khateeb Mohamed A. and Abdel-Shafy Sally H., Drinking water issue in north-west sinai: the problem and solution in a case study, Egyptian. J. Chemistry, 59(2), 229-240 (2016).

5. Smith W.E. and Minamata A.M. "New Engineer, $4: 36(1975)$

6. Mcfeter G.A., "Drinking Water Microbiology Pregress and Recent Developments" SpringlerVerlag, Berlin, p. 544 (1989).

7. United Nation Educational Scientific and Cultural Organization (UNESCO) Meeting basic needs. World Water Assessment Programme (WWAP). http://www.unesco.org/water/wwap/facts_figures/ basic_needs.shtml.Accessed 11 Aug. 2009 (2009).
8. Camper A.K., Lechevallier M.W., Broadway S.C., and McFeters G.A., Applied and Environmental Microbiology, Sept., p.434-438 (1989).

9. Rosenzweig W.D., "Biohazards of Drinking Water Treatment" Chapter 7, Lewis Publishers, Ann Arber, pp.85-93 (1988).

10. Ray C, and Jain R. (Eds.), "Drinking water Treatment, Strategies for Sustainability" Springer Science Business Media B.V. (2011). DOI: 101007/978-94-007-01104-4-2

11. Rosenzeig, W.D. and Pipes, W.O., Wat. Sci. Tach. 20 (11/12), 153 (1988).

12. A Report of the Safe Drinking Water Committee, "Drinking Water \& Healthy". Part 1, Chapter V, National Research Council. Washington, D.C. (1977).

13. Chapman R.F. "The Insects Structure and Function" The English Universities Press Itd, pp. 270 (1973).

14. American Public Health Association APHA/ AWWA/ WPCF "Standard Methods for the Examination of water \& Wastewater" $15^{\text {th }}$ ed., Washington, D.C. (2005).

15. Wiggles- Worth, V.B. "The Principles of Insects Physiology" The Williams \& Wilkins Co., Baltimore, pp. 353 (1972).

16. Abdel-Shafy, Hussein I. and Abdel-Shafy Sally H. "Membrane technology for water and wastewater management and application in egypt: review article" Egyptian. J. Chemistry, Accepted for publication on: Dec. (2016).

17. Strathmann H., Giorno L. and Drioli E., in "An Introduction to Membrane Science and Technology". Institute on Membrane Technology, CNR-ITM at University of Calabria, CNR Roma (2006) 332-336.

18. Abdel-Shafy, Hussein I. and Kamel Aziza H. "Groundwater in Egypt Issue: Resources, location, Amount, Contamination, Protection, Renewal, Future Overview" Egyptian. J. Chemistry, 59, (3) 321- 362 (2016).

19. Abdel-Shafy, Hussein I., Mohamed R. Farid and Aly M. Shams El-Din "water-hyacinth from nile river: chemical contents, nutrient elements and heavy metals" Egyptian. J. Chemistry, 59(2), 131143 (2016).

(Received 14/8/2017; accepted 24/9/2017) 


\section{التلوث الكيميائي والبيولوجي لمياه الثرب المخزنة في حاويات لفترات مختلفة لانعدام الكلور

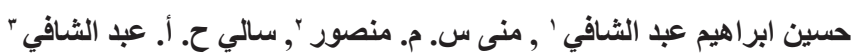

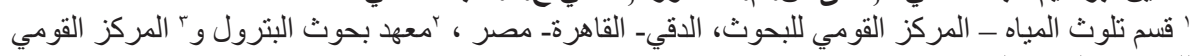

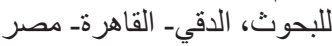

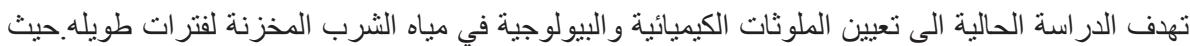

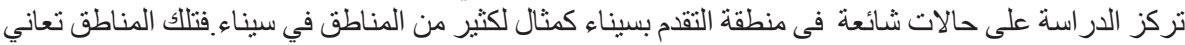

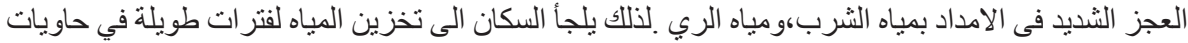

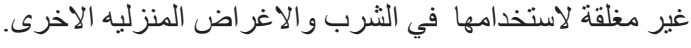

تركز الدراسة على تأثير الكلور المتبقي في المياه وعلاقته بوجود التلوث الكيميائي والبيولوجي ويشمل :زيادة

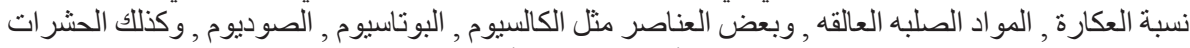

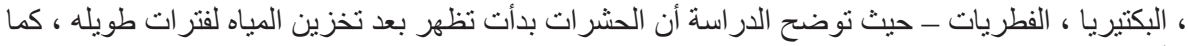

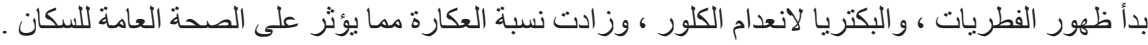

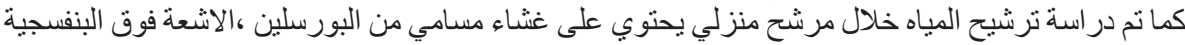

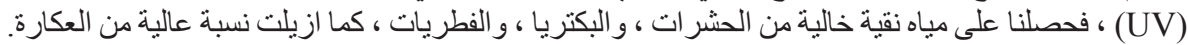

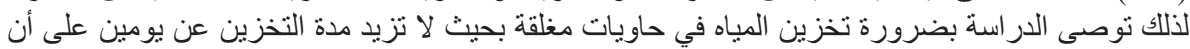

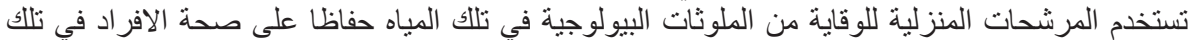
المناطق . 